\title{
HISTORICAL INCREMENTALISM AND ITS EFFECTS ON THE (MIS) PERCEPTION OF LIBERALISM IN RUSSIA. GUIDANCE FROM IN-COUNTRY EXPERTS
}

\author{
Loredana Maria Simionov \\ Researcher, PhD at the Centre for European Studies, Faculty of Law Alexandru \\ Ioan Cuza University \\ Iasi, Romania \\ loredana.simionov@uaic.ro

\section{Ramona Tiganasu} \\ Researcher, PhD at the Centre for European Studies, Faculty of Law Alexandru \\ Ioan Cuza University \\ Iasi, Romania \\ ramona.frunza@uaic.ro
}

\begin{abstract}
The Ukraine crisis and the events that followed have brought about an unprecedented strain within EU-Russia system of relations, highlighting the major drift between Russia and the Western, liberal world. EU's deficiency to predict the lack of results in influencing Russia's agenda has translated into an incapability of understanding the Russian mind-set: for the Russian society, the economic crisis and welfare deficit, as a direct result of Western sanctions, did not materialise into a decline in the population's support for Kremlin, nor into a rising criticism towards the president as being held accountable for the country's economic situation. On the contrary, the popularity of President Putin has increased considerably since the crisis in Ukraine. A significant explanatory power of such trends resides in the historical incrementalism of the Russian society with deep roots in a series of dramatic events and sudden changes over
\end{abstract}


the last century. Thus, the current paper revolves around capturing Russians' attitudes and perceptions regarding the concept of liberalism and the Western model of democracy, through in-country expert interviews; such an approach could contribute to a better understanding of the Russian society and implicitly to building a more effective dialogue and communication between the two actors.

\section{Keywords}

European Union, liberalism, Russia

\section{INTRODUCTION}

The recent events in the shared neighbourhood have drastically estranged Russia from European structures and has marked the end of the post-Cold War European order. Since 2014, perceptions of Russia have drastically shifted from a "strategic partner" to a "key strategic challenge" (EU Global Strategy, 2016) bringing back chills from the Cold War era. The approach and discourse have changed from transformation through cooperation to isolation/containment through sanctions and "selective engagement". This paradigm shift has various long-term implications, not only for the two actors involved, but also for the welfare and security of the extended Europe. However, despite the recent change in discourse, EU's main objective towards Russia still remains that of transforming it into a Western model of democracy (Leonard and Krastev, 2014; Mearsheimer, 2018).

The latest dynamics in EU (West)-Russia relations have been thoroughly discussed and analysed by experts, analysts and academia alike, with a majority of voices blaming the Russian leader alone for the deadlock; however, such unilateral approaches are quite simplistic, as they fail to focus on the deeper structural causes and issues of the current EU-Russia crisis. As such, the EU on its own presents several inconsistencies in its approach towards Russia that weigh heavily on the effectiveness of its soft power instruments: 
First, the EU's actions and attitudes towards Russia are mainly based on a personalist approach, revolving around Russia's leader (Krastev and Leonard, 2014; Mearsheimer, 2014). The Western approach in dealing with and understanding Russia tends to be fixating on understanding the Russian leader. Thus, the assumption "to understand Putin is to understand Russia" is a major simplification of the stakes. On a long run, in order to enhance its efficiency in the region EU should re-orient from Kremlin to society.

Second, the EU's agenda and actions in the Eastern Neighbourhood is generally based on its normative objectives of exporting its model, without considering these countries' ability and willingness to transform (Korosteleva, 2012). Specifically towards Russia, EU's ability to influence Kremlin or generate transformational processes at society's level was limited at best. For example, the latest actions against Russia - imposed economic sanctions - have failed to counteract its behaviour or agenda. The EU's failure to both anticipate and respond effectively to the Russian government's domestic and foreign policy, have some deep structural causes that go beyond the "blame game" (Kuzio, 2018) between the West and Russia.

Third, the EU focuses on the diffusion of its liberal norms and values in order to broaden the spectrum of security beyond the borders, through a missionary approach. Such a perspective prevents it from perceiving some realities specific to the post-Soviet space, and to grasp the possibility of being perceived from the outside as a threat. The utter gratitude and openness of the new Eastern members towards the European project has further encouraged the EU in its endeavour, making it difficult to understand that it might be perceived as a threat. Opposed to these countries that had direct support and involvement of the West in overcoming the harsh transition, Russia has eventually found its way out on its own (Przeworski, 2015). During transition EU mistook Russia's weakness for a desire to convert to its model and subsequently for a tacit acceptance of the new European security order. Instead of confronting this reality, the EU gets often stuck in its own model, failing to see Russia for what it is, not for what is should be; fixated on changing Russia, the EU does not focus on answering the obvious and most important questions, necessary to build a proper strategy: What do Russians feel about liberalism - the foundation of the 
Western world? Do they understand the liberal values and principles or the development model based on them?

The current paper aims at answering the above questions, having as a starting point the following assumptions: Russians do not yearn for the Western liberal model of development as they do not understand what liberalism really stands for (1) and the majority of Russians perceive liberalism through the specific historical context of the '90s, failing to associate it with its basic values and principles (2).

Thus, the addressed topic is of particular relevance considering the context of an increasing pressure to enhance the effectiveness of EU's foreign policy in its eastern neighbourhood. An in-depth understanding of Russians' perceptions, attitudes and expectations would increase Russia's predictability which would facilitate on the one hand and constructive dialogue with Russia's political leaders and, on the other hand, the development of a better communication strategy of EU's public diplomacy that could lead to the democratic transformation of Russia by generating bottom-up synergies within society, based on its own values and traditions.

\section{METHODS AND THEORETICAL BACKGROUND}

In order to prove the research assumptions, the current study is based on an exploratory research project of capturing Russians' attitudes and perceptions about the Western model, principles and values through a series of in-country expert interviews. Research on the ground in Russia was funded through a national research competition by the Romanian Government and it took place from February to September 2017. The research aimed at capturing Russians' perceptions vis-à-vis the EU, liberalism, democracy and the Western model of development As such, there were conducted 23 semi-structured in-depth interviews with Russian experts from academia, independent analysts, civil society and mass-media representatives. All the conducted interviews were direct (face to face), except for three via Skype, had an average of 45 minutes and took place in Moscow from March to September 2017. 
The interview's main question - Could you please explain, in your opinion, what the Russian people understand by the concept of liberalism? Please state some connotations or some associated words to liberalism that have some specific meaning for the Russian society and culture. - was meant to capture and test the perceptions and attitudes of the Russian mind-set towards liberalism. The question was built in more general lines in order to offer the experts more flexibility in their visions and interpreting, through a semi-structured interview. As such, according to the experts' answers there were introduced additional questions customised to each expert for clarifications, for gaining more information or for deepening the analysis.

The interviewed experts represent journalists, researchers, political analysts, academia, independent experts, and reporters from various most relevant institutions in Russia, such as: Russian Economic University of Moscow "Plekhanov", Moscow State University Lomonosov, Russian Academy of Sciences, Aston University - London, U.K., Echo Moscow Radio, Forbes Magazine - Moscow, Russian International Affairs Council, News Agency TARTASS, The Embassy of the United States of America in Moscow, Carnegie Moscow, Centre for Strategic Research - Moscow, European Council for Foreign Relations (ECFR)/ European Union Institute for Security Studies (EU ISS), Moscow Kosmolets, Kommersant, etc. All the experts were interviewed in order to capture their views and expertise regarding Russians' perceptions of the concept of liberalism, its principles and values.

Considering that liberalism is such a broad systematic philosophy that entails several dimensions, there is a huge body of literature in various fields that discuss, debate and analyse this current. This paper solely refers to the broad liberal thought with its definite and fundamental conceptions of equality and individual liberty, and its related values (respect for diversity, human rights, solidarity, rule of law, etc.) and how it is perceived by the Russian people. It has already been noted that liberalism does not represent a homogenous ideology, but rather a discontinuous mixture of concepts, values, debates, institutional arrangements and practices (Weinstock 2007, 244). In Russia there is a long tradition of liberal thinking, starting with the second half of the $18^{\text {th }}$ century and being on a steady rise in Russian socio-political and cultural life until the 
Bolshevik Revolution (Kara-Murza 2007). As such, liberalism represented a very strong driving force of Russian history, even though it has been partially defeated by other competing trends (Pivovarov in Chebankova 2014). However, even during the Soviet Era liberalism was not completely eradicated, as Khrushchev and Brezhnev years have witnessed, among other trends, a new resurgence of liberal thought (Pivovarov in Chebankova 2014). Nowadays, there are two main paradigms in Russian political thought: the liberals (Europeanists) and the conservatives (Eurasianists), paradigms that express Russians' dual identity between Europe and Asia (Mileski 2015). The liberals aim at diffusing European norms and values in the cultural, political, and social spheres, whereas traditionalists revolve around the Eurasian dimension of Russia's identity and its uniqueness. However, this is a broad perception of the political thought. According to Chebankova (2014) the liberal thought could be broadly split into these two "competing traditions that fuel competing trends within the realms of policy-making, political activism and practice" [...], which she later identifies within Russian liberal thought as rival groups: "pluralistic moderate and monistic radical". While monistic refers to universal primacy of liberty, the pluralist group value pluralism and diversity. The common denominator for these groups is "freedom, constitutionalism, rule of law, and equality of opportunity"", whereas they differ in their "attitudes toward the nature of truth, knowledge and progress". Regarding the latest (progress), the one side supports Russia's uniqueness, whereas the other "defends the Eurocentric political path toward freedom as an ultimate destiny". Chebankova (2014) goes further by associating these differences to the answers to "existential questions that concern Russia's place in history, international relations, pace of reforms, attitude toward society, Russia's identity, and finally, tasks for the future". Regarding the task of contemporary liberalism Chebankova $(2014,360)$ noted that it is "neither a slavish idolization of the state, nor the perpetual mimicking of oppositionist sentiment or an ardent attempt to uproot the government; and it is certainly not a radicalization of the liberal discourse with the view of imposing liberalism forcefully upon the reluctant population. Rather, the task is viewed as resetting liberalism so that it could occupy a rightful place in the debate that takes place over the construction of Russia's new civic identity". 
Although it has never taken deep roots in Russia, liberalism was always present in Russian political thought, even during Soviet times. Moreover, liberalism and its values has always represented a significant movement that led to Russia's modernization, reforms and progress; liberal reforms starting with Alexander the Liberator in 1860s. However, the collective mind-set has not recovered after the harsh transition with most citizens perceiving liberalism wrongfully; they still see it through the eyes of the '90s, as something "harmful, foreign and not suitable for Russia" (according to the majority of in-country experts). The evidence to support this claim is provided by the conducted interviews where incountry experts validate that the Russian mind-set has an overall negative perceptions of liberalism.

When it comes to capturing societal attitudes and perceptions, it is also wellestablished in literature the crucial role that historic events have in shaping them. One of the conclusions formulated from the perspective of neoinstitutionalism, with immediate and major implications on reform and transformation processes, is that the evolution of economic and social processes depends on the past and this dependence manifests itself through the lack of pre-transition patterns that would support reforms (Cornia and Popov 1997; David 2000; Pierson 2004; Andreev 2006; Darvas 2010; Flachaire et al. 2014). The deep impact of the transition and the path dependence should be taken into account when outlining EU agenda and strategy towards Russia. Although this path dependency is valid for all the Eastern Europe, the misperception of liberalism is specific mainly to Russians. The difference between Russia and the other Eastern European countries, now EU member states, is how they have succeeded in overcoming the harsh transitions. For instance, if Eastern European countries have been supported by the EU in their reforms and integration into the Common Market, Russia has find the way out on its own. Subsequently, for the EU's postcommunist member states, communism was considered to be the cause of transition, whereas the West and liberalism have saved the day. For Russians, the opposite has happened: development and recovery were associated with the Russian leader (President Putin), whereas the cause for the demise was interpreted as the West and its liberalism interfering in Russia. Moreover, an overwhelming majority of Russians (Levada Centre, 2018) consider that any 
change and transformation of Russia should be orchestrated from inside the country, as "no one understands nor cares about Russia's problems better than the Russians". Within Russia the disdain for liberals and democrats stems from the chaos they left behind in many of the lives of Russia's citizens. This could also explain the popular support for Putin that seems to rest in part on restoring society's faith in the "power of law to bring a disordered society back into order" (Carnaghan 2007, 64). As such, Russians' misperceptions of liberalism are not surprising, considering that the ' 90 s were defined by reforms and transformation processes generated by the harsh transition.

\section{INTERVIEWS RESULTS AND INTERPRETATIONS}

\subsection{Connotations and associations}

Although the responses and visions varied in terms of length and structure, when it comes to capturing attitudes, historical incrementalism is the most highlighted cause for the negative perceptions of liberalism. Overall, a wide majority of experts (over $80 \%$ ) had similar opinions and views regarding the analysed perceptions and attitudes so there was no need for statistical delimitations within the interpreting section of the paper. As such, there is a wide consensus among experts that liberalism has a negative connotation in Russia and it is perceived in a historical context, mainly associated with the events in the '90s (the harsh transition).

"Liberalism for Russians is something equal to Western model of democracy; it is associated with the 90 s and all its instability. Actually, liberalism is associated with those political forces that did pursue the austerity of liberal reforms and the shock therapy. Liberals are seen as people who are anti-Russian, who wanted to subordinate Russia to the West and who have destroyed the Soviet economy." (Russian political analyst, August, 2017) 
Moreover, there were identified various patterns and common visions among experts which helped in better shaping and analysing Russians' perceptions of liberalism, from being a purely economic concept, to being associated with nonconformist artists and anarchy. Moreover, the wide majority of connotations and associations are negative, despite this rich pallet of perceptions. The most common words associated with liberalism throughout the interviews were: West, transition, chaos, oligarchs, foreign, unpatriotic, non-conformists, artists, and no respect for Russia's values, traditions and history.

"[...] if we are talking about the specific meaning in Russian culture, we should bear in mind that Russian liberalism has never realized itself in full manner. In this sense, for Russian society, liberalism is considered something strange, brought form the outside that does not have roots in Russia." (Russian professor at Moscow State University, May, 2017)

Moreover, few experts (13\%) consider that most Russians do not even use the word liberalism in this form. The more commonly used word deriving from it is liberal which is mainly associated with the oligarchs who have impoverished the Russian people during and after the transition.

I think liberalism is not even a word for Russians, but liberal is a word that is used a lot. Early, in post-communist period, in the 80's, during perestroika, the word was democrats and democracy. So people who were opposed to the communist system, to the one-party rule, were the democrats. Now, people who are modernised, westernised, employed in post-industrial economy, who are broad minded as far as the world beyond is concerned, who do not regard the west as the enemy, are referred to as liberals. [...] The word liberal would probably be used more as it applies to the economy [...]However, I would not say that people in general are interested in this terminology, probably not [...]. (Russian independent expert, NGO Representative, July, 2017)

In Russians' minds, not only have the "liberals" impoverished the people, but they are still in power, still managing the economy and the country's finances. It is generally known that with few exceptions, Putin did not truly eradicate their power, but has only infiltrated his own favourites to their ranks (Przeworski 2015, 39): Putin accepts that liberals are in charge of the economy because they know 
about market economy. This is the ordinary Russian story about liberals. (Russian scientific researcher, June, 2017)

To experts' interviews results have confirmed the research assumptions, as an overwhelming majority of respondents $(78 \%)$ consider that: Russians do not yearn for the Western liberal model of development as they do not truly understand what liberalism really stands for (1) and majority of Russians perceive liberalism through the specific historical context of the '90s, failing to associate it with its basic values and principles (2). Apart from these two major assumptions, the interviews' results indicate other significant patterns of Russians' perceptions regarding the analysed concept, as follows: liberalism does have a negative connotation in Russia (95\% of experts); liberalism is perceived as pure economic liberalism (78\%); liberalism is seen as libertarianism (65\%) although Russians yearn for liberal values and freedoms (78\%).

Considering the interviews' results, we could state that the negative perceptions of liberalism, deeply rooted in the historical context of the '90s, could explain why the liberal democracy does not appeal so much to the Russian people.

\subsection{Liberalism as pure economic liberalism mixed with libertarianism}

Given the association with the transition period, it is not difficult to grasp why the Russian people see liberalism in terms of economics. The '90s came after decades-long ideological confrontation between USSR's state-controlled economy versus the Western's liberal, market economy. Moreover, the collapse of Communism there seemed to be one dominant political goal in the world, and especially in Eastern European countries' agendas: liberal democracy and free market economy. As such, after the Soviet Union collapsed, the years that followed were seen and perceived as the times when Russians dropped the command economy and embraced its liberalisation. When things turned sour there came the disappointment in the Western model and all poverty, instability and weak institutions were attributed to liberalism. As such, this contextual meaning of the word liberal in Russia does not have much to do with politics, democracy or society, but with economy: 
"In Russia, the term liberalism acquired the meaning of economic liberalism, associated with Chubais-Gaidar generation of politicians. Even today, very often liberalism does not apply to political liberalism, it doesn't mean you are in favour of democracy or that you are socially liberal; it means that you are supporting free market deregulation and privatisation, meanwhile you can support authoritarian government. Lots of Russia's liberals think that the state should play a lesser role in the economy but they are ok if authoritarianism delivers on state deregulation. What is called in Russia liberal it doesn't mean democracy.[...] All the liberals of Russia or the ones who designed Russian economy for the last 20 years can live with political authoritarianism". (Expert on Russia, EUISS, June, 2017)

Historically, Russian liberalism regarded the state as its friend and partner, and, if managed "properly, virtuously, and progressively", as the source of social stability. The main enemy of Russia's contemporary liberalism remains social chaos, and from that point of view, liberals "do not want to demolish the state. Rather, they want to improve it with the view of ensuring harmony, prosperity, and stable development" (in Tretyakov et al. 2008).

When the processes of liberalisation and democratisation have begun in the $90 \mathrm{~s}$, the state lost control and the processes collapsed, and the newly formed structure dominated all the others. As Przeworski (2015) noted, the Russian state had a very difficult task: to ensure the formation and consolidation of institutions and civil society, whereas keeping a particular balance between state and society. It was the transition that made people comprehend the importance of the state and its role in society, leading them to put the state first, as without it there is only chaos. As such, in Russian mind-set, it was essential to have a strong state before any other process of modernisation or liberalisation could begin. It is indeed a pre-condition of democratisation to have a strong, stable state in order to begin democratisation from above, at least for the launching process, until new political and social forces, uncontrolled by the state, under rules of law are able to have relations with each other and the state without destroying it or allowing the emergence of chaos and anarchy.

"When people think of liberalism, they actually think of libertarianism, they think of the trauma of the 90s, humiliation, chaos, poverty, and instability. In Soviet Union there was stability, especially economic one. It was a huge transformation of the country with 
living conditions that degraded with over 70-80\%. In Romania or in Poland there was a national idea of returning to Europe which has saved them from being totalitarian or from fully coming back to communist past. In Russia things were and are different: for the transition people denounce the West, as Russia recovered on its own". (Political Analyst, July, 2017)

As experts' opinions indicate, this is the most important fear of the Russian people: that the current social and political forces are not strong enough to be independent. The transition and all the other dramatic events from the last century have undoubtedly left deep marks in Russian's mind-set, to such extent that they have a particular fear of changes and instability (Simionov and Pascariu 2018). As such, that historical context is remembered as chaotic, unstable and governed by very weak institutions, some experts considering that in most Russians' collective minds, liberalism equals libertarianism.

\subsection{What about the liberal values?}

The way liberalism means different things in different countries in terms of political groups, the same way its values are perceived and interpreted. For instance, liberalism means different things in different countries: in the US, liberal is applied for the Democratic Party, meaning to the left, whereas in Europe liberals refer to centrist or right wing parties. The liberal values in Russia are already there, people already yearn for them. The difference is that they are not attributed to the Western world, nor to the liberal model of democracy, they are called "basic human values". Majority of experts note that Russians yearn for liberal fundamental values, like freedom and equality (as the endgame) but do not support the liberal world's means (Western model of democracy) to achieve them.

"Russians like the values and freedoms of liberalism but they call them basic human values associated to ancient Greek but to modern Europe. [...] Liberal values are not so popular among Russian people, although Russians are not paternalistic, nor too traditional. There is a high degree of tolerance and diversity in Russia in terms of ethnicities and religions. [...] it is difficult to understand what the values of liberalism 
stand for. Late 19th century there was an attempt to focus on the individual, to address the individual and its rights and freedoms which is very liberal in essence. A lot of the times Russian thinkers in Soviet Union tried to stir us away to focusing on the individual but they never fully succeeded; right now, we do want the same freedoms and have the same values, the difference is that we do not consider them European/Western, but universal". (Journalist, April, 2017)

The fact that liberal values and principles are appealing to the Russian people could be an important trait for the EU to consider in drawing its agenda and strategy towards Russia. Transformation into a liberal democracy is a very longterm process that has already started in Russia not too long ago. For instance, Przeworski (2015), in complementing Andrew Jack's vision on Russia's transformation, has noted that although Russia is still far from the Western standards of liberal democracy, if we were to consider "the starting positions from which it has been moving toward democracy, one can assert with confidence that the country has made tremendous progress along this path. Thus, the objective evaluation of a regime depends on the extent to which the ongoing processes are viewed in a historic context, with due consideration of national peculiarities of the country" (24). Moreover, the fact that liberalism is a strange concept for the Russian society, it does not mean that the existing liberals in Russia should be ignored. They might represent a driving force that could help diffuse European norms and values within the Russian society, helping them in getting more familiar with the liberal tradition. As Chebankova (2014) suggests the

"Policy developers, public opinion makers, and those merely interested in bridging sociocultural gaps between Russia and the West must be more attuned to engaging representatives of the pluralist liberal tradition [...] I am not suggesting that this must take place at the expense of their intellectual exchange with the radicals. It is merely a thought that the uncritical playing to the whims of the radicals not only prevents Russia from building democracy but also creates a bitter feeling on the part of Russian society that sees Western agency in promoting dogmatic and radical ideas, which are alien to both Russia and the West." 


\section{CONCLUSIONS}

Shifting our attention from Kremlin to society might bring about valuable input in designing and improving EU's agenda and actions towards Russia. As such, in EU's endeavours to change Russia, there were recurrently omitted Russians' attitudes and perceptions towards our liberal democracy model. Traditionally, liberalism is not alien to Russians. There is a long history of liberalism even during Soviet times. However, the communist ideology (path dependency), coupled with the fact that liberal democracy has not taken deep roots in Russia, made the society reluctant to the concept of liberalism. As such, Russians give liberalism a specific historical context, associating it with the transition of the '90s and with the West's failed attempt to modernise and liberalise Russia. This misperception highlights that transforming Russia is a long process still in the making. Patience and all sorts of civic initiatives are needed to encourage and diffuse the values and principles of liberalism among Russia's civil society. Furthermore, the values and principles governing the liberal model of democracy are appealing to Russians, some of which are already guided by them. Moreover, a liberal Russia should be perceived as a very long-term goal, based on a bottom-up approach, and linked to a long-term European strategy, centred on society, common goals and interests. Strengthening public democracy and communication should be at the heart of any issue related to EU's cooperation with Russia; in such critical moments it is desirable to intensify dialogue, not isolation.

\section{REFERENCES}

- Andreev, S. 2006. "Path Dependence during the EU Fifth Enlargement: Comparing East-Central and Southeast Europe". Quarterly Journal of Political Science, Vol. 1, pp. 87-115.

- Carnaghan, E. 2007. Do Russians Dislike Democracy? https:/www.cambridge.org/core/terms. https://doi.org/10.1017/S1049096507070114 
- Chebankova, E. 2014. “Contemporary Russian liberalism”. Post-Soviet Affairs, Vol. 30, No. 5, pp. 341-369.

- Cornia, G.A., Popov, V. 1997. "Transition Strategies, Growth and Poverty”. UN/WIDER, Helsinki.

- Darvas, Z. 2010. "Beyond the Crisis: Prospects for Emerging Europe”. Breugel Working Paper. No. 06.

- David, P. A. 2000. "Path dependence, its critics and the quest for historical economics". in Garrouste, P. and Ioannides, S. (eds.). Evolution and Path Dependence in Economic Ideas: Past and Present. Cheltenham: Edward Elgar Publishing.

- $\quad$ Flachaire, E., García-Peñalosa, C., Konte, M. 2014. "Political versus Economic Institutions in the Growth Process". Journal of Comparative Economics, Vol. 42, Issue 1, pp. 212-229.

- Korosteleva, E. 2012. The European Union and its Eastern Neighbours: towards a more ambitious partnership? https://kar.kent.ac.uk/37649/

- Kara-Murza, A., ed. 2007. Rossiyskiy Liberalizm: Idey i lyudi [Russian Liberalism. Ideas and People] Moscow: Fond Liberal'naya Missiya.

- Kara-Murza, A. 2009. “Problemy grazhdanstva i identichnosti v Russkom liberal'nom diskurse XI-XX vekov [Problems of Citizenship and Identity in Russian Liberal Discourse of the Nineteenth to Twentieth Centuries]. Paper presented at the Grazhdanstvo v Usloviyakh Globalizatsii [Citizenship in Conditions of Globalization] Conference. Moscow: Institute of Philosophy, Russian Academy of Sciences."

- Krastev, I. and Leonard, M. 2014. “The New European Disorder". European Council on Foreign Relations. accessed on October 21st, 2016. http://www.ecfr.eu/publications/summary/the_new_european_disorder3 22, European Council for Foreign Relations.

- Kuzio, T. 2018. "Russia-Ukraine Crisis: The Game Blame, Geopolitics and National Identity". Europe-Asia Studies, Vol. 70, No. 3, 462-473.

- Levada Centre. 2018. http://www.levada.ru/eng

- Mearsheimer, J. J. 2014 (7 November). "Why the Ukraine Crisis Is the West's Fault. The Liberal Delusions That Provoked Putin", Foreign Affairs.

- Mearsheimer, J. J. 2018, The Great Delusion: Liberal Dreams and International Realities. London: Yale University Press.

- Mileski, T. 2015. "Identifying the Eurasian orientation in modern Russian geopolitical thought", Eastern Journal of European Studies, Vol. 6, Issue 2, 177187. 
- Pierson, P. 2004. Politics in Time: History, Institutions, and Social Analysis. Princeton: Princeton University Press.

- Przeworski, A. 2015. Democracy in a Russian mirror, Cambridge: Cambridge University Press.

- Simionov, L. and Pascariu, G. 2018. "Une perspective generale sur la diplomatie publique de l'Union Europeenne vers la Russie" [A General Perspective on the European Union's Publiuc Diplomacy Towards Russia], De la Communication en diplomatie, Hermes, Le Revue, pp. 148-157, CRNS: Paris.

- Tretyakov, V., Y. Pivovarov, A. Kara-Murza, I. Diskin, and B. Makarenko. 2011 (3 April). "Rossiya i liberalizm. Vechnyy mezal'yans? [Russia and Liberalism. An Eternal Mis-Alliance]." Chto Delat', no. 290. http://www.youtube.com/watch?v¹/4b4u9sSG_5Xo

- Tretyakov, V., A. Kara-Murza, K. Remchukov, B. Titov, and I. Bunin. 2008. "Liberalizm kak politika v Rossii [Liberalism as Policy in Russia]." Chto Delat, no. 224.

- Tretyakov, V., V. Fadeyev, Y. Pivovarov, I. Yurgens, and V. Pligin. 2013 (24 February). "Kto diskreditiruyet liberalizm v Rossii? [Who is Discrediting Liberalism in Russia?]." Chto Delat? no. 346.

-Weinstock, D. 2007. "Liberalism, Multiculturalism, and the Problem of Internal Minorities." In Multiculturalism and Political Theory, edited by A. Laden, and D. Owen, 244-264. Cambridge: Cambridge University Press. 